\title{
Myo-inositol content in pteridophytes and the isolation and characterization of L-myo-inositol-1-phosphate synthase from Diplopterygium glaucum
}

\author{
D. R. Chhetri ${ }^{1 *}$, A. K. Mukherjee ${ }^{2}$ and J. Adhikari $^{3}$
}

${ }^{1}$ Plant Physiology and Biochemistry Laboratory, Post Graduate Department of Botany, Darjeeling Government College, Darjeeling-734 101, WB, India; '2Department of Biotechnology, Bengal College of Engineering and Technology Bidhan Nagar, Durgapur-713 212, WB, India; ${ }^{3}$ Biochemistry Laboratory, Department of Botany, Presidency College, College Street, Kolkata, WB, India; *Corresponding author: munal@sancharnet.in

Received: 15/03/2006, Accepted: 28/05/2006

Myo-inositol is involved in normal growth and development of all living organisms and L-myo-inositol-1-phosphate synthase (MIPS; EC: 5.5.1.4) is responsible for its de novo synthesis. This enzyme has been reported for a number of life forms including plants, animals and bacteria. In the present study free myo-inositol has been detected in the common pteridophytes found in the Darjeeling Himalayas and the enzyme, L-myo-inositol-1-phosphate synthase has been partially purified from Diplopterygium glaucum (Thunb.) Nakai. A crude homogenate from the reproductive pinnules of D. glaucum was subjected to streptomycin sulphate precipitation and 0-70\% ammonium sulphate fractionation followed by successive chromatography through DEAEcellulose, Hexylagarose and BioGel A- $0.5 \mathrm{~m}$ columns. This resulted in a partial purification of the enzyme of about 81 -fold with $13.5 \%$ recovery. The pteridophytic MIPS specifically utilized D-glucose-6-phosphte and $\mathrm{NAD}^{+}$as its substrate and co-factor, respectively. It shows a $\mathrm{pH}$ optimum between 7.0 and 7.5 while the temperature maximum was $30^{\circ} \mathrm{C}$. The enzyme activity was stimulated by $\mathrm{NH}_{4}^{+}$, slightly inhibited by $\mathrm{Na}^{+}, \mathrm{Ba}^{2+}$ and $\mathrm{Cd}^{2+}$, and strongly inhibited by $\mathrm{Li}^{+}, \mathrm{Zn}^{2+}$ and $\mathrm{Hg}^{2+}$. EDTA, pCMB and some substrate isomers like glucose-1-phosphate, fructose-6-phosphte and galactose-6-phosphate were inhibitory to the enzyme. The apparent molecular weight of the native D. glaucum MIPS was determined to be approximately $171 \mathrm{kDa}$.

Key words: D-glucose-6-phosphate, Gleicheniaceae, inositol synthase, myo-inositol.

Conteúdo de myo-inositol em pteridófitas e o isolamento e caracterização da sintase de L-myo-inositol-1-fosfato de Diplopterygium glaucum: Myo-inositol está envolvido no crescimento e desenvolvimento de todos os organismos vivos e a enzima sintase do L-myo-inositol-1-fosfato (MIPS; EC: 5.5.1.4) é responsável pela sua síntese de novo. Esta enzima tem sido relatada em um número grande de plantas, animais e bactérias. No presente estudo myo-inositol não complexado foi detectado em pteridófitas comuns encontradas em Darjeeling Himalayas e a enzima sintase do L-myo-inositol-1-fosfato foi parcialmente purificada a partir de Diplopterygium glaucum (Thunb.) Nakai. Um extrato protéico não purificado de pinulas reprodutivas foi precipitada com sulfato de estreptomicina e $0-70 \%$ sulfato de amônia seguido de sucessivas cromatografias em colunas de DEAE-celulose, Hexylagarose e BioGel A. Este procedimento resultou na purificação parcial de 81 vezes, com recuperação de $13.5 \%$. A MIPS dessa pteridófita usou especificamente D-glicose-6-fosfato and NAD ${ }^{+}$como substrato e cofator, respectivamente. Mostrou $\mathrm{pH}$ ótimo entre 7,0 e 7,5, enquanto a temperatura ótima foi $30^{\circ} \mathrm{C}$. A atividade da enzima foi estimulada por $\mathrm{NH}_{4}^{+}$, pouco inibida por $\mathrm{Na}^{+}, \mathrm{Ba}^{2+}$ e $\mathrm{Cd}^{2+}$, e fortemente inibida por $\mathrm{Li}^{+}, \mathrm{Zn}^{2+}$ e $\mathrm{Hg}^{2+}$. EDTA, pCMB e alguns substratos isômeros, como glicose-1-fosfato, frutose-6-fosfato e galactose-6-fosfato inibiram a enzima. A massa molecular aparente da MIPS de D. glaucum é aproximadamente $171 \mathrm{kDa}$.

Palavras-chave: Gleicheniaceae, D-glicose-6-fosfato, inositol synthase, myo-inositol. 


\section{INTRODUCTION}

Myo-inositol is a central component of several biochemical pathways. Inositol metabolism is essential for the development of plants, animals and some microorganisms. The essential role of inositol in many cellular processes including membrane formation, cell wall biogenesis, stress response and signal transduction have been well documented (Lackey et al., 2003). Myo-inositol is the precursor of all inositol-containing compounds including phosphoinositides and inositol phosphates. It is formed by the conversion of $\mathrm{D}-$ Glucose-6-Phosphate (G-6-P) to L-myo-inositol-1-phosphate (I-1-P) by the enzyme L-myo-inositol-1-phosphate synthase (MIPS; EC: 5.5.1.4) and is subsequently dephosphorylated by inositol monophosphatase (EC: 3.1.3.25) to myo-inositol (Lohia et al., 1999). The MIPS reaction has been reported for archea (Chen et al., 2000), bacteria (Bachhawat and Mande, 1999; 2000), protozoa (Lohia et al., 1999), lower plants (Donahue and Henry, 1981a; 1981b; Escamilla et al., 1982; Dasgupta et al., 1984; RayChoudhury et al., 1997; Benaroya et al., 2004; Chhetri et al., 2005), higher plants (Loewus and Loewus, 1971; Loewus et al., 1978; Ogunyemi et al., 1978; Adhikari and Majumder, 1983; Johnson and Sussex, 1995; Johnson and Wang, 1996; Chun et al., 2003) and animals (Pittner and Hoffmann-Ostenhof, 1976; 1979; Maeda and Eisenberg Jr., 1980; Adhikari and Majumder, 1988; Chiu et al., 2003). The present study reports the occurrences of free myo-inositol in different pteridophytes. Partial purification of MIPS and characterization of the partially purified enzyme is reported here for Diplopterygium glaucum (Thunb.) Nakai (Family-Gleicheniaceae).

\section{MATERIAL AND METHODS}

Plant material: Fresh specimens of pteridophytes, Dicranopteris linearis Bedd., Diplazium dilatatum B1., Diplopterygium glaucum (Thunb.) Nakai, Equisetum debile Roxb., Lycopodium cernuum L., Polypodium quercifolium L., Pteridium aquilinum (L.) Kuhn. and Selaginella megaphylla Bak. were collected from their natural habitats in and around the Darjeeling hills (ca $2134 \mathrm{~m}$ asl) in the Eastern Himalayas. Each experiment was carried out using three replicates under similar conditions.

Extraction and purification of MIPS: Reproductive pinnules $(100 \mathrm{~g})$ of Diplopterygium glaucum (D. glaucum) were collected fresh in the morning, washed twice with cold, sterile distilled water and homogenized in a chilled mortar and pestle in two volumes of $50 \mathrm{mM}$ tris-acetate buffer ( $\mathrm{pH} 7.5$ ) containing $0.2 \mathrm{mM}$ of ME. The crude homogenate was passed through four layers of muslin and the filtrate centrifuged at $1,000 \mathrm{~g}_{n}$ for $5 \mathrm{~min}$. The supernatant was again centrifuged at 11,400 $\mathrm{g}_{n}$ for $20 \mathrm{~min}$ and the pellet discarded. The supernatant was dialyzed overnight against $50 \mathrm{mM}$ trisacetate (pH 7.5) buffer containing $0.2 \mathrm{mM} \mathrm{ME}$ and the clear supernatant was collected from the dialysis bag. The 11,400 $\mathrm{g}_{n}$ clear supernatant obtained from the reproductive pinnules of D. glaucum was subjected to streptomycin sulphate treatment to a final concentration of $2 \%(\mathrm{w} / \mathrm{v})$ with constant stirring. The mixture was kept at $0^{\circ} \mathrm{C}$ (in ice) for $15 \mathrm{~min}$ and then centrifuged at $11,400 \mathrm{~g}_{n}$ for $15 \mathrm{~min}$. The supernatant (streptomycin sulphate-treated fraction) was collected and fractionated with 0-70 \% $\left(\mathrm{NH}_{4}\right)_{2} \mathrm{SO}_{4}$. The precipitated protein fraction was dialyzed and this fraction (0-70\% ammonium sulphate fraction) was adsorbed onto DEAE-cellulose and the mixture packed in a glass column. The adsorbed proteins were eluted from the column with a linear gradient of 0-0.5 $\mathrm{M} \mathrm{KCl}$ (figure 1A). The active DEAE-cellulose fractions (DEAE-cellulose fraction) were chromatographed on a Hexylagarose column and eluted with $50 \mathrm{mM}$ Imidazole$\mathrm{HCl}$ ( $\mathrm{pH} 7.5$ ) buffer containing $0.2 \mathrm{mM} \mathrm{ME}$ (figure 1B). The active Hexylagarose fractions (Hexylagarose fraction) were pooled and loaded onto a column of BioGel A- $0.5 \mathrm{~m}$ and the proteins eluted with the extraction buffer (figure 1C). The active fractions (BioGel fraction) were pooled and concentrated before further use.

Enzyme activity assay: The MIPS activity was assayed by the procedure of Barnett et al. (1970) with slight modifications (Adhikari et al., 1987). The enzyme assay mixture contained $50 \mathrm{mM}$ tris-acetate $(\mathrm{pH} 7.5), 14 \mathrm{mM} \mathrm{NH}_{4} \mathrm{Cl}, 0.8 \mathrm{mM} \mathrm{NAD}^{+}$, $5 \mathrm{mM}$ ME, $5 \mathrm{mM}$ G-6-P and an appropriate aliquot (100$200 \mu \mathrm{g}$ ) of enzyme protein in a total volume of $0.5 \mathrm{~mL}$. The mixture was incubated at $37^{\circ} \mathrm{C}$ for $1 \mathrm{~h}$ after which the reaction was terminated by adding $0.2 \mathrm{~mL}$ of $20 \%$ chilled TCA. An equal volume of $0.2 \mathrm{M} \mathrm{NaIO}_{4}$ was added to the deproteinized supernatant followed by a second incubation at $37^{\circ} \mathrm{C}$ for $1 \mathrm{~h}$ for the oxidation of the MIPS reaction product myoinsositol-1-phosphate, with concomitant release of inorganic phosphate. The excess periodate was destroyed by $1 \mathrm{M}$ $\mathrm{Na}_{2} \mathrm{SO}_{3}$. Simultaneously, appropriate non-periodate controls, without the $\mathrm{NaIO}_{4}$ and $\mathrm{Na}_{2} \mathrm{SO}_{3}$ treatments, were also run. The activity of the enzyme was determined by estimating the product-specific release of inorganic phosphate from myo-insositol-1-phosphate formed in the MIPS reaction. The amount of inorganic phosphate released from the MIPS reaction product upon periodate oxidation was estimated by 
the method of Chen et al. (1956) and protein was determined according to the method of Bradford (1976) with BSA as a standard. The protein content in fractions obtained from column chromatography was determined by measuring absorbance at $280 \mathrm{~nm}$.

Protein electrophoresis: Polyacrylamide gel electrophoresis of the BioGel fraction was performed under non-denaturing conditions using $0.75 \mathrm{~mm}$ gels following the method of Bollag et al. (1996). The protein sample (30 $\mu \mathrm{g} / \mathrm{lane})$ was loaded onto a gel system containing $8 \%$ separating gel and 4 $\%$ stacking gel and electrophoresed in a Biotech regular slab gel apparatus at $4^{\circ} \mathrm{C}$ at $100 \mathrm{~V}$. For MIPS activity in the gels, one of the replicate gels was sliced into $5 \mathrm{~mm}$ fragments and each fragment extracted with $250 \mu \mathrm{L}$ of $50 \mathrm{mM}$ tris-acetate buffer $(\mathrm{pH} 7.5)$ at $0^{\circ} \mathrm{C}$ for $30 \mathrm{~min}$. The extracts were then assayed for MIPS activity.

$M_{\mathrm{r}}$ determination: The apparent molecular weight of the native MIPS obtained from the reproductive pinnules of $D$. glaucum was determined by gel filtration through a Sephadex G-200 column. The molecular weight of the enzyme was determined from the relative elution volume of the active fractions by comparison with the standard curve prepared using as marker proteins, catalase $(221.6 \mathrm{kDa})$, bovine serum albumin dimer (133.3 kDa), phosphorylase-b (97.4 $\mathrm{kDa})$, ovalbumin (43 kDa), carbonic anhydrase (29 kDa) and lysozyme $(14.3 \mathrm{kDa})$.
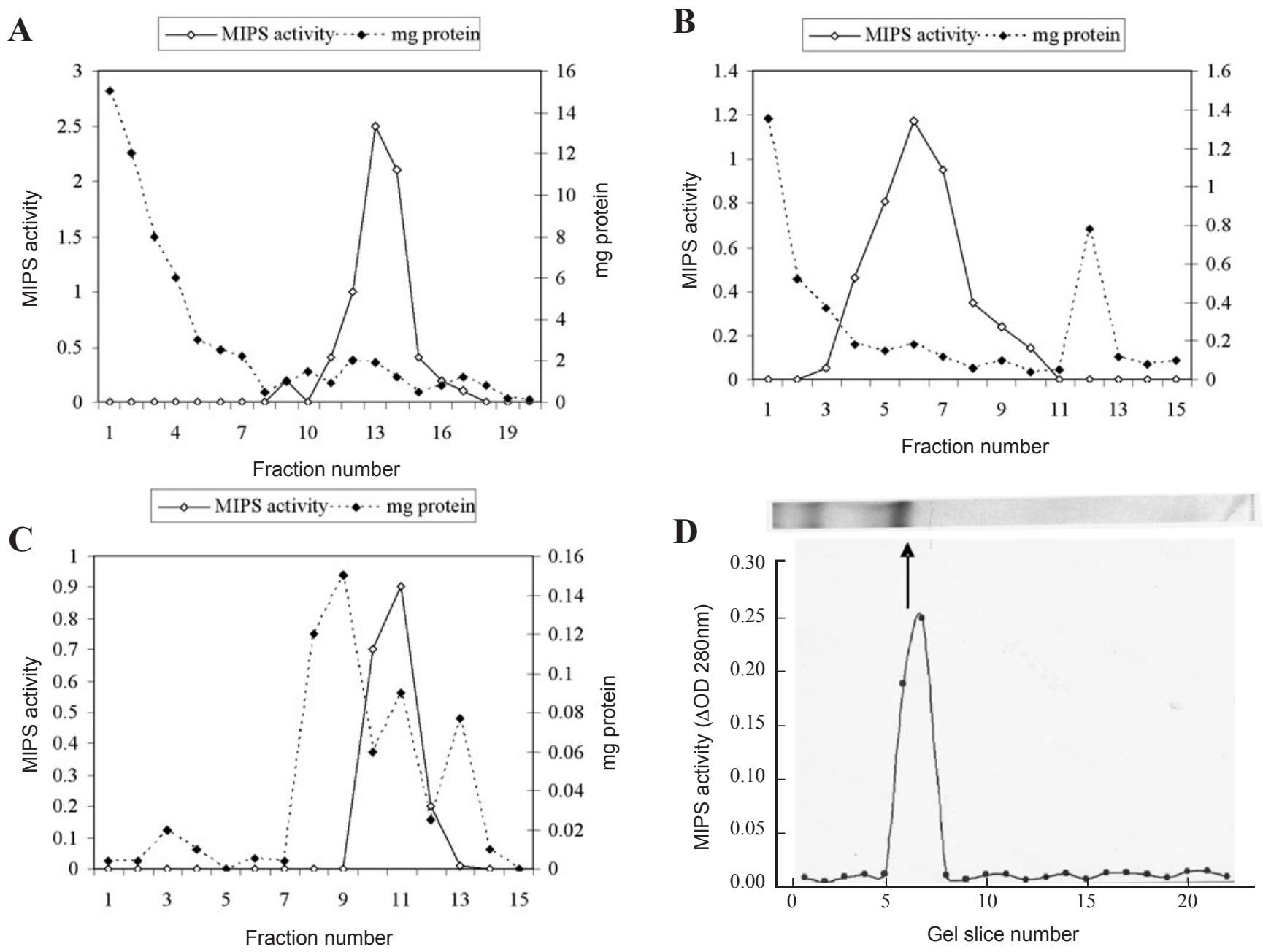

Figure 1. Elution profile of D. glaucum MIPS from a (A) DEAE-cellulose column [MIPS activity expressed as $\mu$ mol I-1-P produced $(2 \mathrm{~mL} \text { fraction })^{-1} \mathrm{~h}^{-1}$, (B) Hexylagarose column [MIPS activity expressed as $\mu$ mol I-1-P produced $\left.(1.25 \mathrm{~mL} \text { fraction })^{-1} \mathrm{~h}^{-1}\right],(\mathrm{C})$ Biogel A- $0.5 \mathrm{~m}$ column [MIPS activity expressed as $\mu$ mol I-1-P produced $(0.75 \mathrm{~mL} \text { fraction })^{-1} \mathrm{~h}^{-1}$ ] and (D) PAGE profile showing the MIPS activity of the corresponding band. 
Free myo-inositol determination: Free myo-inositol was isolated by the method of Charalampous and Chen (1966). The extracted sample was passed through a mixed-bed column of Dowex-1-Cl (100-200 mesh) and Amberlite IR-120 (Na-form) and the free myo-inositol was ultimately isolated by one dimensional descending chromatography on Whatman no.1 paper. The content of free myo-inositol was estimated spectrophotometrically (Gaitonde and Griffiths, 1966) using a standard curve prepared from known concentrations of pure myo-inositol.

\section{RESULTS AND DISCUSSION}

Determination of free myo-inositol from pteridophytes: Appreciable quantities of free myo-inositol (the final product of myo-inositol biosynthesis) were detected in vegetative and reproductive parts of different pteridophytic species (table 1). It was revealed that the quantities of free myo-inositol in almost all plant parts were moderately high. Free myo- inositol content was detected in relatively large quantities in the reproductive pinnules of Lycopodium cernuum and Diplopterygium glaucum. Different inositol derivatives are known to be essential for all life forms (Majumder et al., 2003). Hence, the detection of free myo-inositol in these pteridophytes is not surprising.

Purification of L-myo-inositol-1-phosphate synthase: The enzyme, MIPS was isolated and purified from the reproductive pinnules of D. glaucum. A summary of the purification of MIPS is given in table 2. Chromatographic profiles of proteins resolved from the $\left(\mathrm{NH}_{4}\right)_{2} \mathrm{SO}_{4}$ fraction of the crude homogenate of $D$. glaucum reproductive pinnules are shown in figure $1(\mathrm{~A}-\mathrm{C})$. The BioGel A-0.5m chromatography (figure 1C) revealed that the MIPS from D. glaucum was retained and eluted as a single sharp peak with the extraction buffer. In the present study, an overall purification of about 81-fold was achieved for this enzyme with about $13.5 \%$ recovery based on total activity.

Table 1. Distribution of free myo-inositol in vegetative and reproductive structures of different pteridophytic species (Values are mean $\pm \mathrm{SE}, \mathrm{n}=3$ ), $\mathrm{FW}=$ Fresh Weight.

\begin{tabular}{|c|c|c|c|}
\hline Family & Plant species & Plant part & $\begin{array}{c}\text { Free myo-inositol content } \\
(\mathrm{mg} / \mathrm{g} \mathrm{FW})\end{array}$ \\
\hline Gleicheniaceae & Dicranopteris linearis Bedd. & $\begin{array}{l}\text { Vegetative } \\
\text { Sori }\end{array}$ & $\begin{array}{l}0.70 \pm 0.19 \\
1.94 \pm 0.14\end{array}$ \\
\hline Gleicheniaceae & Diplopterygium glaucum (Thunb.) Nakai & $\begin{array}{l}\text { Vegetative } \\
\text { Sori }\end{array}$ & $\begin{array}{l}2.50 \pm 0.36 \\
3.70 \pm 0.61\end{array}$ \\
\hline Dryopteridaceae & Diplazium dilatatum $\mathrm{B} 1$. & $\begin{array}{l}\text { Vegetative } \\
\text { Sori }\end{array}$ & $\begin{array}{l}1.20 \pm 0.38 \\
1.10 \pm 0.11\end{array}$ \\
\hline Equisetaceae & Equisetum debile Roxb. & $\begin{array}{l}\text { Vegetative } \\
\text { Strobili }\end{array}$ & $\begin{array}{l}0.92 \pm 0.10 \\
0.60 \pm 0.03\end{array}$ \\
\hline Lycopodiaceae & Lycopodium cernuum $\mathrm{L}$. & $\begin{array}{l}\text { Vegetative } \\
\text { Strobili }\end{array}$ & $\begin{array}{l}2.88 \pm 0.19 \\
3.60 \pm 0.20\end{array}$ \\
\hline Polypodiaceae & Polypodium quercifolium L. & $\begin{array}{l}\text { Vegetative } \\
\text { Sori }\end{array}$ & $\begin{array}{l}3.68 \pm 0.31 \\
0.80 \pm 0.17\end{array}$ \\
\hline Hypolepidaceae & Pteridium aquilinum (L.) Kuhn & $\begin{array}{l}\text { Vegetative } \\
\text { Sori }\end{array}$ & $\begin{array}{l}0.82 \pm 0.05 \\
1.22 \pm 0.12\end{array}$ \\
\hline Selaginellaceae & Selaginella megaphylla Bak. & $\begin{array}{l}\text { Vegetative } \\
\text { Strobili }\end{array}$ & $\begin{array}{l}3.52 \pm 0.17 \\
2.48 \pm 0.12\end{array}$ \\
\hline
\end{tabular}

Table 2. Summary of partial purification of L-myo-inositol-1-phosphate synthase from D. glaucum (Values are mean \pm SE, $\mathrm{n}=3$ ).

\begin{tabular}{|c|c|c|c|c|c|}
\hline Purification step & $\begin{array}{l}\text { Protein content } \\
\qquad(\mathrm{mg} / \mathrm{mL})\end{array}$ & $\begin{array}{l}\text { Specific activity } \\
(\mu \text { mol I-1-P } \\
\text { produced. } \mathrm{mg}^{-1} \\
\left.\text { protein. } \mathrm{h}^{-1}\right)\end{array}$ & $\begin{array}{l}\text { Total activity } \\
(\mu \text { mol I-1-P } \\
\text { produced. } \mathrm{mg}^{-1} \\
\left.\text { protein. } \mathrm{h}^{-1}\right)\end{array}$ & $\begin{array}{c}\text { Recovery } \\
(\%)\end{array}$ & $\begin{array}{l}\text { Purification } \\
\text { (fold) }\end{array}$ \\
\hline Homogenate & $0.47 \pm 0.05$ & $0.12 \pm 0.02$ & $13.43 \pm 5.55$ & $100.00 \pm 15.29$ & $1.0 \pm 0.15$ \\
\hline DEAE-cellulose fraction & $0.49 \pm 0.05$ & $1.21 \pm 0.15$ & $7.07 \pm 1.30$ & $52.66 \pm 6.19$ & $10.01 \pm 1.61$ \\
\hline Hexylagarose fraction & $0.12 \pm 0.01$ & $5.02 \pm 0.53$ & $5.28 \pm 0.50$ & $39.34 \pm 2.44$ & $41.40 \pm 1.93$ \\
\hline BioGel fraction & $0.04 \pm 0.01$ & $9.98 \pm 2.15$ & $1.81 \pm 0.10$ & $13.47 \pm 1.08$ & $80.99 \pm 4.19$ \\
\hline
\end{tabular}


Requirements for G-6-P and NAD for D. glaucum MIPS activity: The $D$. glaucum MIPS has been found to utilize G6-P as the exclusive substrate since other hexose and pentose phosphates could not replace it. However, this enzyme could partially utilize D-galactose-6-phosphate $(9.38 \%)$ and Dmannose-6-phosphate (1.42\%). Omission of NAD ${ }^{+}$resulted in a loss of enzyme activity of about $67 \%$. In a similar study it was found that when $\mathrm{NAD}^{+}$was not added to the rice enzyme, its activity was reduced to $55 \%$ of the maximum (Funkhouser and Loewus, 1975).

Enzyme stability: Stability of D. glaucum MIPS varied with the different stages of purification. While the low speed supernatant remained active for 20-22 days with insignificant loss of activity when stored at $-20^{\circ} \mathrm{C}$, the BioGel-A $0.5 \mathrm{~m}$ purified fraction maintained only about $80 \%$ of its activity up to 10-12 days when stored at an identical temperature. Addition of the enzyme stabilizers, 2-mercaptoethanol (ME) or dithiothreitol (DTT) increased the shelf-life of the enzyme by $7-10$ days.

Enzyme concentration and the time linearity: The $D$. glaucum MIPS exhibited enzyme activity proportional to protein concentration up to $280 \mu \mathrm{g}$ of protein under optimal assay conditions. The rate of enzyme reaction proceeded linearly up to 90 min with G-6-P as the substrate. An earlier study with Acer pseudoplatanus showed time linearity up to
150 min with a G-6-P concentration under $4 \mathrm{mM}$ (Loewus and Loewus, 1971)

Effect of temperature and $\mathrm{pH}$ : The enzyme was highly active in the temperature range of $20-40^{\circ} \mathrm{C}$ with $30^{\circ} \mathrm{C}$ as the temperature maximum. Temperature maxima of $35^{\circ} \mathrm{C}$ were found for the cytosolic enzymes from both higher and primitive plants (RayChoudhury et al., 1997). The $D$. glaucum MIPS exhibited optimum activity at a $\mathrm{pH}$ range of 7.0-7.5. MIPS from other plant sources exhibited similar $\mathrm{pH}$ optima (Gumber et al., 1984; RayChoudhury et al., 1997)

Effect of ammonium concentration: The D. glaucum MIPS activity was stimulated by $\mathrm{NH}_{4}{ }^{+}$in a concentration-dependent manner up to $12 \mathrm{mM}$. The stimulation was to the order of 1.3fold (approx.). Similarly, in yeast, maximum activity was not reached until the $\mathrm{NH}_{4}^{+}$concentration was raised to $10 \mathrm{mM}$ (Chen and Charalampous, 1965). With $\mathrm{NH}_{4} \mathrm{Cl}$ treatment, the enzyme activity was found to increase two-fold in Euglena gracilis (Dasgupta et al., 1984) and four-fold in Entamoeba histolytica (Lohia et al., 1999).

Effect of organic modifiers: Of the several organic compounds tried as effectors for the D. glaucum MIPS, three substrate isomers, Glucose-1-phosphate, Fructose-6-phosphate and Galactose-6-phosphate exhibited between $6 \%$ and $14 \%$ enzyme inhibition. On the other hand, the sulfhydryl binding

Table 3. Effect of some substrate isomers and $\mathrm{pCMB}$ on D. glaucum L-myo-inositol-1-phosphate synthase activity (Values are mean $\pm \mathrm{SE}, \mathrm{n}=3$ ).

\begin{tabular}{|c|c|c|c|}
\hline Compound & $\begin{array}{l}\text { Concentration } \\
(\mathrm{mM})\end{array}$ & $\begin{array}{l}\text { Specific activity ( } \mu \text { mol I-1-P } \\
\left.\text { produced.mg }{ }^{-1} \text { protein. } h^{-1}\right)\end{array}$ & Percent activity \\
\hline Control & 0.0 & $9.166 \pm 1.069$ & $100.00 \pm 11.66$ \\
\hline D-glucose-1-phosphate & $\begin{array}{l}1.0 \\
2.5 \\
5.0\end{array}$ & $\begin{array}{l}9.219 \pm 0.394 \\
8.711 \pm 0.686 \\
7.943 \pm 0.652\end{array}$ & $\begin{array}{l}100.56 \pm 4.27 \\
95.02 \pm 7.88 \\
86.64 \pm 8.21\end{array}$ \\
\hline D-fructose-6-phosphate & $\begin{array}{l}1.0 \\
2.5 \\
5.0\end{array}$ & $\begin{array}{l}9.037 \pm 1.363 \\
7.913 \pm 0.375 \\
7.863 \pm 0.383\end{array}$ & $\begin{array}{l}98.58 \pm 15.08 \\
86.33 \pm 4.74 \\
85.77 \pm 4.87\end{array}$ \\
\hline D-galactose-6-phosphate & $\begin{array}{l}1.0 \\
2.5 \\
5.0\end{array}$ & $\begin{array}{l}9.216 \pm 1.356 \\
9.028 \pm 0.343 \\
8.631 \pm 0.805\end{array}$ & $\begin{array}{l}100.53 \pm 14.71 \\
98.49 \pm 3.80 \\
94.16 \pm 9.33\end{array}$ \\
\hline pCMB & $\begin{array}{l}1.0 \\
2.5 \\
5.0\end{array}$ & $\begin{array}{l}6.852 \pm 0.330 \\
3.119 \pm 0.079 \\
2.524 \pm 0.112\end{array}$ & $\begin{array}{l}74.75 \pm 4.82 \\
34.03 \pm 2.54 \\
27.53 \pm 4.83\end{array}$ \\
\hline
\end{tabular}


agent, para-chloromercurobenzoate $(\mathrm{pCMB})$ recorded $73 \%$ inhibition for the enzyme at $5 \mathrm{mM}$ concentration (table 3 ). The pine pollen MIPS was also inhibited to about $80 \%$ by $0.1 \mathrm{mM}$ pCMB (Gumber et al., 1984), however, it did not affect the enzyme activity of Streptomyces griceus (Sipos and Szabo, 1989).

Determination of $K_{\mathrm{m}}$ values: The $K_{\mathrm{m}}$ values of the substrate and the co-factor was determined by means of LineweaverBurk plots. The $K_{\mathrm{m}}$ value for G-6-P was found to be $0.83 \mathrm{mM}$ and that of the co-factor $\mathrm{NAD}^{+}$was calculated as $0.44 \mathrm{mM}$. The $K_{\mathrm{m}}$ for G-6-P in case of $D$. glaucum MIPS is comparable to that of the yeast enzyme which has a value of $1.18 \mathrm{mM}$. However, the $K_{\mathrm{m}}$ for $\mathrm{NAD}^{+}$of the $D$. glaucum enzyme is quite different from that of the yeast enzyme which has a value of $8 \mathrm{mM}$ (Donahue and Henry, 1981b).

Effect of monovalent and divalent cations: The effect of different metal ions was tested using chloride salts of metals. Of the monovalent cations tested $\mathrm{K}^{+}$had little effect, $\mathrm{Na}^{+}$played a minor inhibitory role and $\mathrm{Li}^{+}$was strongly inhibitory. In the case of divalent cations it was found that $\mathrm{Ca}^{2+}$ and $\mathrm{Mg}^{2+}$ exhibited no effect, $\mathrm{Ba}^{2+}$ slightly inhibited, $\mathrm{Cd}^{2+}$ moderately inhibited, while $\mathrm{Zn}^{2+}$ and $\mathrm{Hg}^{2+}$ strongly inhibited the enzyme activity (table 4).

Effect of sugar alcohols: The MIPS activity from D. glaucum was found to be little influenced by the presence of sugar alcohols like galactitol, mannitol and myo-inositol, the end product of the synthase and phosphatase reactions. However, synthase preparations from Acer pseudoplatanus cell culture (Loewus and Loewus, 1973) and Arabidopsis thaliana (Johnson and Sussex, 1995) are inhibited by the presence of inositol.

Effect of EDTA: In the concentration range of $0-100 \mathrm{mM}$, EDTA had a very significant effect on D. glaucum MIPS activity causing inhibition in a concentration-dependent manner. Earlier studies with other plants have shown that the production of MIPS is repressed by the addition of EDTA (Loewus and Loewus, 1983).

PAGE profile and corresponding enzyme activity: The MIPS activity was determined from $5 \mathrm{~mm}$ gel slices after the BioGel-A $0.5 \mathrm{~m}$ fraction of D. glaucum was electrophoresed under non-denaturing conditions. Only a single major band of protein was found and this coincided with the position of the enzyme activity (figure 1D).

Molecular weight: The apparent molecular weight $\left(M_{\mathrm{r}}\right)$ of the native $D$. glaucum MIPS was determined by gel-filtration on a Sephadex G-200 column. The value of molecular mass was about $171 \mathrm{kDa}$. The molecular weight of D. glaucum MIPS was found to be comparable to the enzyme from other sources. The comparable $M_{\mathrm{r}}$ of MIPS from other reported sources are 155 from Pinus ponderosa pollen (Gumber et al., 1984), 179

Table 4. Effect of monovalent and divalent cations on L-myo-inositol-1-phosphate synthase activity in D. glaucum. Values are mean $\pm \mathrm{SE}(\mathrm{n}=3), \pm \mathrm{SE}$ is shown in the parenthesis.

\begin{tabular}{|c|c|c|c|c|c|c|c|c|c|}
\hline \multirow{2}{*}{$\begin{array}{l}\text { Concentration of cations } \\
(\mathrm{mM})\end{array}$} & \multicolumn{9}{|c|}{ Specific activity $\left[\mu\right.$ mol I-1-P produced $(\mathrm{mg})^{-1}$ protein $\left.\mathrm{h}^{-1}\right]$} \\
\hline & $\mathrm{K}^{+}$ & $\mathrm{Na}^{+}$ & $\mathrm{Li}^{+}$ & $\mathrm{Ca}^{2+}$ & $\mathrm{Mg}^{2+}$ & $\mathrm{Ba}^{2+}$ & $\mathrm{Cd}^{2+}$ & $\mathrm{Zn}^{2+}$ & $\mathrm{Hg}^{2+}$ \\
\hline 0 & $\begin{array}{l}7.750 \\
(1.12)\end{array}$ & $\begin{array}{l}7.750 \\
(1.12)\end{array}$ & $\begin{array}{l}7.750 \\
(1.12)\end{array}$ & $\begin{array}{l}7.750 \\
(1.12)\end{array}$ & $\begin{array}{l}7.750 \\
(1.12)\end{array}$ & $\begin{array}{l}7.750 \\
(1.12)\end{array}$ & $\begin{array}{l}7.750 \\
(1.12)\end{array}$ & $\begin{array}{l}7.750 \\
(1.12)\end{array}$ & $\begin{array}{l}7.750 \\
(1.12)\end{array}$ \\
\hline 2 & $\begin{array}{l}7.825 \\
(0.69)\end{array}$ & $\begin{array}{l}7.537 \\
(1.22)\end{array}$ & $\begin{array}{l}6.341 \\
(1.37)\end{array}$ & $\begin{array}{l}7.740 \\
(0.50)\end{array}$ & $\begin{array}{l}7.683 \\
(0.08)\end{array}$ & $\begin{array}{l}7.530 \\
(0.66)\end{array}$ & $\begin{array}{l}7.410 \\
(0.21)\end{array}$ & $\begin{array}{l}6.430 \\
(0.83)\end{array}$ & $\begin{array}{l}6.228 \\
(0.61)\end{array}$ \\
\hline 4 & $\begin{array}{l}7.908 \\
(0.58)\end{array}$ & $\begin{array}{l}7.280 \\
(1.06)\end{array}$ & $\begin{array}{l}6.050 \\
(0.52)\end{array}$ & $\begin{array}{l}7.810 \\
(0.76)\end{array}$ & $\begin{array}{l}7.750 \\
(0.46)\end{array}$ & $\begin{array}{l}7.420 \\
(0.32)\end{array}$ & $\begin{array}{l}7.105 \\
(0.24)\end{array}$ & $\begin{array}{l}6.215 \\
(0.57)\end{array}$ & $\begin{array}{l}4.479 \\
(0.79)\end{array}$ \\
\hline 6 & $\begin{array}{l}8.119 \\
(1.62)\end{array}$ & $\begin{array}{l}7.034 \\
(1.34)\end{array}$ & $\begin{array}{l}5.325 \\
(1.01)\end{array}$ & $\begin{array}{l}7.800 \\
(1.01)\end{array}$ & $\begin{array}{l}7.650 \\
(0.57)\end{array}$ & $\begin{array}{l}7.238 \\
(0.75)\end{array}$ & $\begin{array}{l}6.930 \\
(0.15)\end{array}$ & $\begin{array}{l}5.624 \\
(0.23)\end{array}$ & $\begin{array}{l}2.435 \\
(0.18)\end{array}$ \\
\hline 8 & $\begin{array}{l}8.375 \\
(1.40)\end{array}$ & $\begin{array}{l}(6.250 \\
(1.12)\end{array}$ & $\begin{array}{l}4.296 \\
(0.01)\end{array}$ & $\begin{array}{l}7.618 \\
(0.18)\end{array}$ & $\begin{array}{l}7.684 \\
(0.26)\end{array}$ & $\begin{array}{l}6.966 \\
(0.24)\end{array}$ & $\begin{array}{l}6.439 \\
(0.54)\end{array}$ & $\begin{array}{l}4.845 \\
(0.42)\end{array}$ & $\begin{array}{l}1.013 \\
(0.19)\end{array}$ \\
\hline 10 & $\begin{array}{l}8.108 \\
(0.19)\end{array}$ & $\begin{array}{l}6.000 \\
(0.25)\end{array}$ & $\begin{array}{l}3.328 \\
(0.24)\end{array}$ & $\begin{array}{l}7.716 \\
(0.18)\end{array}$ & $\begin{array}{l}7.817 \\
(0.33)\end{array}$ & $\begin{array}{l}6.750 \\
(0.75)\end{array}$ & $\begin{array}{l}5.610 \\
(0.45)\end{array}$ & $\begin{array}{l}4.190 \\
(0.29)\end{array}$ & $\begin{array}{l}0.500 \\
(0.08)\end{array}$ \\
\hline
\end{tabular}


from Euglena gracilis (RayChoudhury et al., 1997) and 180 from Entamoeba histolytica (Lohia et al., 1999).

\section{DISCUSSION}

Our objective was to determine the occurrence of myoinositol in the pteridophyte group and partially purify the enzyme MIPS. It was found that appreciable quantities of free myo-inositol were present in all the species and plant parts examined. The accumulation may reflect the status of myo-inositol biosynthesis of each species. The apparent molecular weight of the D. glaucum MIPS native enzyme was determined as $170,828 \mathrm{Da}$ which is consistent with the fact that in plants the molecular weight of the native cytosolic MIPS varies between 179 to $200 \mathrm{kDa}$ (RayChoudhury et al., 1997). The enzyme from $D$. glaucum was highly specific for G-6-P. However, some enzyme activity was recorded when galactose-6-phosphate and mannose-6-phosphate were used as substrates. A $\mathrm{NAD}^{+}$-dependent oxido-reductase, identical with MIPS, isomerizes galactose-6-phosphate to тисо-inositol-1-phosphate (Adhikari and Majumder, 1988). In D. glaucum, the biosynthesis of muco-inositol through a metabolic by-pass cannot therefore be ruled out. Furthermore, the utilization of mannose-6-phosphate indicated the concomitant formation of another isomer of inositol. In this context the product identification of galactose-6-phosphate and mannose-6-phosphate utilization may open new avenues of research centered on the biosynthesis of inositol. Though the enzyme exhibits its optimal activity in presence of the coenzyme $\mathrm{NAD}^{+}$, it still could maintain about one third of the total activity when $\mathrm{NAD}^{+}$was not added exogenously. This is due to the presence of endogenous $\mathrm{NAD}^{+}$in the molecular architecture of this enzyme (Adhikari and Majumder, 1983, Dasgupta et al., 1984).

Of the monovalent cations, $\mathrm{K}^{+}$showed no significant effect while $\mathrm{Li}^{+}$exhibited exclusive inhibition of the $D$. glaucum enzyme in a concentration-dependent manner. The $\mathrm{Li}^{+}$-induced decrease in MIPS activity may be attributed to the inhibition of inositol monophosphatase activity ( $\mathrm{Ju}$ et al., 2004). $\mathrm{Na}^{+}$acted as a mild inhibitor of this enzyme as observed for the enzyme from other sources. Divalent cations also exhibited activities similar to those reported earlier from other sources (Wells et al., 1974; Loewus and Loewus, 1980). The strong enzyme inhibition due to heavy metals suggests that one or more free sulphydryl groups are present within the active site of the enzyme (Nelson and Cox, 2000). The D.glaucum MIPS was also inhibited by EDTA in a concentration-dependent manner which is a general feature of all plant enzymes (Dasgupta et al., 1984), in contrast to the same enzyme from animal systems (Maeda and Eisenberg Jr., 1980; Adhikari and Majumder, 1988).

Like all other eukaryotes, the D. glaucum MIPS requires $\mathrm{NH}_{4}^{+}$for optimal activity in contrast to the divalent cationrequiring MIPS of prokaryotes (Majumder et al., 2003). This indicates that the pteridophytic MIPS is a type-III aldolase. The present investigation presents the fundamental evidence for the classic occurrence of the enzyme MIPS and its ultimate product in pteridophytes. Further studies regarding the enzyme in this highly adaptive group of plants may pave the way for bioprospecting for useful genes.

Acknowledgements: The authors are grateful to the University Grants commission, Govt. of India, New Delhi for financing the present work with a minor research project (No. F. PSW-061/99-00 (ERO) to DRC.

\section{REFERENCES}

Adhikari J, Majumdar AL (1983) Differences in thermal stability of the fetal and adult brain myo-inositol-1-phosphate synthase. FEBS Lett. 163:46-49.

Adhikari J, Majumdar AL (1988) L-myo-Inositol-1-phosphate synthase from mammalian brain: partial purification and characterization of the fetal and adult enzyme. Ind. J. Biochem. Biophys. 25:408-412.

Adhikari J, Majumdar AL, Bhaduri TJ, Dasgupta S, Majumdar AL (1987) Chloroplast as a locale of L-myo-Inositol-1phosphate synthase. Plant Physiol. 85:611-614.

Bachhawat N, Mande SC (1999) Identification of the INO 1 gene of Mycobacterium tuberculosis $\mathrm{H} 37 \mathrm{Rv}$ reveals a novel class of Inositol-1-phosphate synthase enzyme. J. Mol. Biol. 291:531-536.

Bachhawat N, Mande SC (2000) Complex evolution of the inositol-1-phosphate synthase gene among archea and eubacteria. Trends Genet. 16:111-113.

Barnett JEG, Brice RE, Corina DL (1970) A colorimetric determination of inositol monophosphates as an assay for D-Glucose-6-phosphate-1L-myo-Inositol-1- phosphate cyclase. Biochem. J. 119:183-186.

Benaroya RO, Zamski E, Tel-Or E (2004) L-myo-inositol-1phosphate synthase in the aquatic fern Azolla filiculoides. Plant Physiol. Biochem. 42:97-102.

Bollag DM, Rozycki MD, Edelstein SJ (1996) Protein Methods. $2^{\text {nd }}$ edn. Wiley-Liss, New York.

Bradford MM (1976) A rapid and sensitive method for the quantitation of microgram quantities of proteins utilizing principle of protein-dye binding. Anal. Biochem. 72:248254.

Charalampous F, Chen IW (1966) Inositol-1-phosphate synthase and Inositol 1-phosphatase from yeast. Methods Enzymol. 9:698-704. 
Chen IW, Charalampous FC (1965) Biochemical studies on inositol. VIII. Purification and properties of the enzyme system which converts glucose-6-phosphate to inositol. J. Biol. Chem. 240:3507-3512.

Chen RS, Toribara TY, Warner H (1956) Microdetermination of phosphorous. Anal. Biochem. 28:1756-1758.

Chen L, Zhou C, Yang H, Roberts MF (2000) Inositol-1phosphate synthase from Archaeoglobus fulgidus is a class II aldolase. Biochemistry 39:12415-12423.

Chhetri DR, Choudhuri M, Mukherjee AK, Adhikari J (2005) L-myo-inositol-1-phosphate synthase: partial purification and characterization from Gleichenia glauca. Biol. Plant. 49:59-63.

Chiu TT, Rogers MS, Briton-Jones C, Haines C (2003) Effects of myo-inositol on the in-vitro maturation and subsequent development of mouse oocytes. Hum. Reprod. 18:408816.

Chun JA, Jin UH, Lee JW, Yi YB, Hyung NI, Kang MH, Pyee JH, Suh MC, Kang CW, Seo HY, Lee SW, Chung $\mathrm{CH}$ (2003) Isolation and characterization of a myoinositol 1-phosphate synthase cDNA from developing sesame (Sesamum indicum L.) seeds: functional and differential expression, and salt-induced transcription during germination. Planta 216:874-80.

Dasgupta S, Adhikari J, Majumdar AL (1984) Myo-inositol1-phosphate synthase from lower plant groups: purification and properties of the enzyme from Euglena gracilis. Physiol. Plant. 61:412-416.

Donahue TF, Henry SA (1981a) Inositol mutants of Saccharomyces cerevisiae: Mapping the INO1 locus and characterizing alleles of INO1, INO2 and INO4 loci. Genetics 98:491-503.

Donahue TF, Henry SA (1981b) Myo-inositol-1-phosphate synthase: Characteristics of the enzyme and identification of its structural gene in yeast. J. Biol. Chem. 256:7077-7085.

Escamilla JE, Contreas M, Martinez A, Pina MZ (1982) Lmyo-Inositol-1-phosphate synthase from Neurospora crassa: Purification to homogeneity and partial characterization. Arch. Biochem. Biophys. 218:275-285.

Funkhouser EA, Loewus FA(1975) Purification of myo-inositol1-phosphate synthase from rice cell culture by affinity chromatography. Plant Physiol. 56:786-790.

Gaitonde MK, Griffiths M (1966) A spectrophotometric method for the determination of microquantities of free inositol in biological material. Anal. Biochem. 15:532.

Gumber SC., Loewus MW, Loewus FA (1984) Myo-inositol-1phosphate synthase from pine pollen: Sulfhydryl involvement at the active site. Arch. Biochim. Biophys. 231:372-377.

Johnson MD, Sussex IM (1995) 1L-myo-Inositol 1-phosphate synthase from Arabidopsis thaliana. Plant Physiol. 107: 613-619.

Johnson MD, Wang X (1996) Differentially expressed forms of 1-L-myo-Inositol 1-phosphate synthase (EC. 5.5.1.4) in Phaseolus vulgaris. J. Biol. Chem. 271:17215-17218.

Ju S, Shaltiel G, Shamir A, Agam A, Greenberg ML (2004) Human 1-D-myo-inositol -3-phosphate synthase is functional in yeast. J. Biol. Chem. 279:21759-21765.
Lackey KH, Pope PM, Johnson MD (2003) Expression of 1L-myo-inositol-1-phosphate synthase in organelles. Plant Physiol. 132:2240-2247.

Loewus MW, Loewus FA (1971) The isolation and characaterisation of D-Glucose 6-phosphate cycloaldolase (NAD-dependent) from Acer pseudoplatanus L. cell cultures. Plant Physiol. 48:255-260.

Loewus MW, Loewus FA (1973) D-Glucose 6-phosphate cycloaldolase: inhibition studies and aldolase function. Plant Physiol. 51:263-266.

Loewus FA, Loewus MW, Maity IB, Rosenfield CL (1978) Aspects of myo-inositol metabolism and biosynthesis in higher plants. In: Wells WW, Eisenberg F Jr. (eds), Cyclitols and Phosphoinositides, pp. 249-267 Academic Press, New York.

Loewus FA, Loewus MW (1980) Myo-inositol: biosynthesis and metabolism. In: Preiss J (ed), The Biochemistry of Plants: Carbohydrate Structure and Function, Vol 3, pp.4376. Academic Press, New York.

Loewus FA, Loewus MW (1983) Myo-Inositol: its biosynthesis and metabolism. Ann. Rev. Plant Physiol. 34:137-161.

Lohia A, Hait NC, Majumdar AL (1999) L-myo-inositol 1phosphate synthase from Entamoeba histolytica. Mol. Biochem. Parasitol. 98:67-79.

Maeda T, Eisenberg F Jr. (1980) Purification, structure and catalytic properties of the 1 L-myo-inositol-1-phosphate synthase from rat testis. J. Biol. Chem. 255:8458-8464.

Majumder AL, Chatterjee A, Ghosh Dastidar K, Majee M (2003) Diversification and evolution of L-myo-inositol-1-phosphate synthase FEBS Lett. 553:3-10.

Nelson DL, Cox MM (2000) Lehninger Principles of Biochemistry. $3^{\text {rd }}$ edn. Worth Publishers, New York.

Ogunyemi O, Pittner F, Hoffman-Ostenhof O (1978) Studies on the biosynthesis of cyclitols. XXXVI. Purification of myoinositol-1-phosphate synthase of the duckweed Lemna gibba to homogeneity by affinity chromatography on NAD sepharose. Molecular and catalytic properties of the enzyme. Hoppe-Seyler's Z Physiol. Chem. 359:613-616.

PittnerF, Hoffman-OstenhofO (1976) Studies on the biosynthesis of Cyclitols. XXXV. On the mechanism of action of myoinositol 1-phosphate synthase from rat testicles. HoppeScylers Z. Physiol. Chem. 357:1667-1671.

Pittner F, Hoffmann-Ostenhof O (1979) Preparation of homogeneous crystals of myo-inositol 1-phosphate synthase from rat testicles--further data on the chemical and catalytic properties of the enzyme (studies on the biosynthesis cyclitols, XXXIX). Mol. Cell. Biochem. 28:23-26.

RayChoudhury A, Hait NC, Dasgupta S, Bhaduri TJ, Deb R, Majumdar AL (1997) L-myo-inositol 1-phosphate synthase of plant sources. Plant Physiol. 115:727-736.

Sipos L, Szabo G (1989) Myo-inositol-1-phosphate-synthase in different Streptomyces griseus variants. FEMS Microbiol. Lett. 65:339-344.

Wells WW, Kuo CH, Naccarato WF (1974) Identification of 6O- $\alpha$-D-mannopyranosyl myo-inositol from Saccharomyces cerevisiae. Biochem. Biophys. Res. Commun. 61:644-650. 